\title{
TYÖ UTOPIOIDEN JÄLKEEN
}

Dominique Méda \& Patricia Vendramin: Réinventer le travail. Paris: PUF 2014.

Työn muutoksesta on tullut yksi keskeisimmistä ja yleisimmistä keskustelunaiheista sanomaja aikakauslehdissä. Tehdastyö vähenee, tieto- ja palvelutyö lisääntyy, työ muuttuu yrittäjämäisemmäksi ja epävarmistuu, työajat muuttuvat joustaviksi, työtilat avoimiksi ja työ yleisesti liikkuvaksi. Samalla muuttuu työhön tähtäävä koulutus ja yleisemmin myös työpaikkoja luova ja ylläpitävä talousjärjestelmä. Työn muutoksesta on esitetty paljon teorioita ja näkemyksiä. Kuten kaikkiin muutoksiin, työn muutokseen kytketään sekä pessimistisiä että positiivisia tulevaisuuden odotuksia. Monilla on paljon sanottavaa koskien työtä ja taloutta, ja siksi myös monenlaiselle työn tutkimukselle on tilausta. Niin Suomea (n. 480000 tosiasiallisesti työtöntä) kuin Eurooppaa (n. 52 miljoonaa tosiasiallisesti työtöntä) vaivaavan massatyöttömyyden aikakaudella vaikuttaa kaikkialla olevan puhetta juuri siitä mitä ihmisiltä eniten puuttuu, nimittäin työstä.

Ranskalainen työntutkimus on laajaa ja perusteellista, aivan kuten missä tahansa länsimaassa. Ranskassa kirjakauppoihin päätyvässä työntutkimuksessa pääpainon tuntuu kuitenkin saavan psykologiapainotteinen "työelämän huonontumista" ja muita työelämässä pahoinvointia ja suuttumusta aiheuttavia ilmiöitä tarkasteleva kirjallisuus. Toki Ranskassa on omat markkinansa myös eräänlaiselle työväenaktivismia tukevalle kirjallisuudelle. Ylipäätään maassa tehdään paljon niin laadullista kuin empiiristäkin työn tutkimusta. Laadullisista tutkimuksista yhtenä viime vuosien mielenkiintoisimpana voidaan pitää Martin Thibaultin teosta Ouvriers malgré tout. Enquête sur les ateliers de maintenan- ce des trains de la Régie autonome des transports parisiens (Paris, Raisons d'agir, 2013), jossa hän tutkii Pariisin joukkoliikenteessä työskentelevien, pääasiassa nuorten ihmisten työtä ja elämää. Suuriin kyselyaineistoihin, tilastoihin ja maidenvälisiin vertailuihin perustuvassa tutkimuksessa laadukasta kärkeä puolestaan edustaa Dominique Médan ja Partricia Vendraminin viime vuonna julkaistu teos Réinventer le travail eli"työn uudelleen keksiminen". Kirja ei kuitenkaan jää pelkäksi empiirisiä faktoja toteavaksi ja työhön liittyviä poliittisia ja yhteiskunnallisia kysymyksiä pakoilevaksi "objektiiviseksi" raportoinniksi, vaan se uskaltaa ottaa kantaa myös aikakautemme suuriin kysymyksiin: yhteiskunnallisen solidaarisuuden purkautumiseen ja ekologisen kriisin asettamiin reunaehtoihin. Kirja kysyykin, mitä työstä tulisi ajatella ja miten sitä tulisi ajatella siihen liitettyjen modernien utopioiden jälkeen.

Kirjan kirjoittajat ovat ranskalaisen ja belgialaisen työn tutkimuksen pitkän linjan tekijöitä. Méda aloitti akateemisen uransa filosofian agrégation-tutkinnolla. Hän on opiskellut Pariisin huippukouluissa, kuten École Normale Supérioressa ja École Nationale d'administrationissa. Tällä hetkellä hän työskentelee sosiologian progessorina Université Paris Dauphinessa ja johtaa Centre d'études de l'emploi -tutkimuskeskusta. Belgialainen Vendramin työskentelee vierailevana professorina Université Louvain-la-Neuvessä ja toimii johtajana ja tutkijana Fondation Travail-Universitéssä Namurin yliopistossa. Hän on väitellyt sosiologian tohtoriksi Louvainin yliopistosta vuonna 2004. Molemmat kirjoittajat ovat julkaisseet lukuisia teoksia ja artikkeleita niin ranskaksi kuin englanniksi.

Réinventer le travail perustuu monipuolisiin aineistoihin. Perustan kirjalle luo Euroopan 
unionin kuudennen puiteohjelman rahoittama Social Patterns of Relations to Work -tutkimushanke, joka toteutettiin vuosina 2006-2008. Siihen osallistui tutkijoita kuudesta maasta (Belgia, Ranska, Saksa, Unkari, Italia ja Portugali) sekä työelämän toimijoita, kuten julkisen vallan ja ammattiliittojen edustajia. Ohjelman tarkoituksena oli tutkia eri sukupolvien suhtautumista työhön, erilaisia sukupolvien välisiä solidaarisuuden ja konfliktin aiheita niin työelämässä kuin muussakin elämässä sekä tuoda esiin näihin liittyviä poliittisia kysymyksiä.

Tutkimus koostui laadullisesta ja määrällisestä osasta sekä erilaisten työhön liittyvien poliittisten toimien vertailusta. Laadullinen aineisto kattoi 163 henkilöhaastattelua kuudesta maasta eri ikäryhmistä (alle 30-vuotiaat, 30-49-vuotiaat sekä yli 50-vuotiaat). Osallistujat olivat tasapuolisesti miehiä ja naisia, koulutettuja ja kouluttamattomia sekä niin vakituisissa kuin prekaareissa töissä työskenteleviä. Yksilöhaastatteluiden lisäksi tutkimusta varten tehtiin myös kahdeksantoista ryhmähaastattelua. Kirjassa on käytetty myös Daniel Mercuren ja Mircea Vulturin Kanadan Quebecissä tekemää kyselytutkimusta. Määrällinen osuus koostui puolestaan suurten kansainvälisten kyselyaineistojen analyysista. Nämä aineistot olivat European Value Study, International Social Survey Programme, European Social Survey, L'Enquête européenne sur les conditions de travail (Eurooppalainen työolotutkimus), EUROSTATin harmonisoima aineisto European Community Household Panelin tutkimuksesta sekä Eurobarometri. Kirjassa käytetyt aineistot ovat siis huomattavan kattavat, minkä vuoksi ne antavatkin hyvän kuvan niin ranskalaisesta kuin yleisestikin keski-eurooppalaisesta työelämästä.

VOIDAANKO VÄLINEELLINEN

SUHTAUTUMINEN TYÖHÖN YLITTÄÄ?

Kirja koostuu viidestä pääluvusta. Niistä ensimmäisessä tarkastellaan työn historiaa pohtien erityisesti sitä, millainen arvo työlle on annettu erilaisissa yhteiskunnissa. Kartoitus lähtee liikkeelle "esitaloudellisista" yhteiskunnista (millä Ranskassa usein viitataan, kuten tässäkin tapauksessa ja ehkä hieman kyseenalaisestikin, alkuperäiskansojen talouteen, jota voidaan tutkia antropologian kautta), siirtyen sitten antiikkiin ja kulkien valistuksen kautta Weberin teeseihin protestanttisuudesta kapitalismin hengen peruspilarina. Peruskertomuksena on tuttu ajatus siitä, kuinka työn asema yhteiskunnassa on kasvanut jatkuvasti. Aiemmin työ, etenkin fyysinen raataminen, oli välttämättömyys eikä sitä juurikaan arvostettu. Viimeistään protestanttisesta reformaatiosta ja teollisesta vallankumouksesta lähtien työlle on kuitenkin annettu erityismerkitys yhteiskuntien vaurauden peruspilarina. Fordismin ja taylorismin myötä työstä tulee entistä välineellisempää ja samalla sisällöllisesti köyhää, monotonista tehdastyötä. 1900-luvun ja 2000-luvun alun vauraus on rakennettu tämänkaltaisen työn perustalle.

Tämä lyhyt kartoitus on hyvä konteksti kirjalle, jonka suurena kysymyksenä ja teesinä on työn uudelleen keksiminen - siis kysymys siitä, voiko valistuksen ja modernin ajan instrumentaalinen ja eräässä mielessä "köyhä" suhtautuminen työhön olla enää jälkimodernin yhteiskunnan perusta. Voisiko työ siis olla jotain muutakin kuin raatamista leivän tai rikkauksien eteen? Tämän saman kysymyksen on muotoillut kenties tarkemmin sveitsiläinen sosiologi Christian Lalive d'Épinay, jonka mukaan modernilla ajalla työ on välineellistä (instrumentaalista) toimintaa palkan vuoksi. Sen avulla yksilö puolestaan pääsee käsiksi kaikkeen siihen, mihin kuluttamalla on mahdollista päästä käsiksi. Kuinka työ siis voisi antaa elämäämme sisältöä ja merkitystä ja samalla ohjata yhteiskunnallista käyttäytymistä ja toimintaa uuteen suuntaan? Kuinka työ voisi olla jotain muuta kuin tätä välineellistä, kulutukseen ja sen äärettömiin mahdollisuuksiin suuntautunutta toimintaa? Kirjan yleisorientaatio muistuttaa paljon Antti Kasvion teosta Kestävä työ ja hyvä elämä (Gaudeamus 2014), ja mielestäni kirjat täydentävät hyvin toisiaan. 
Ensimmäisen osan muut luvut käsittelevät työn erilaisia ulottuvuuksia (työ tuotantona, ihmislajille tyypillisenä toimintana sekä tulojen ja oikeuksien jakajana), muutosta työn etiikassa (velvollisuusetiikasta yksilöllisen "kukoistuksen" etiikkaan), erilaisia työn tutkimukseen ja tulkintaan sopivia kategorioita (välineellinen ja ei-välineellinen ulottuvuus, jälkimaterialistinen ulottuvuus, työn päämäärien pohdinta) sekä työn tutkimusta koskevia metodeja (määrällisen ja laadullisen tutkimuksen tarjoamat mahdollisuudet ja käytetyt materiaalit). Viimeinen osio tarkastelee siis sitä, kuinka voidaan tutkia yksilöiden, yhteisöjen ja yhteiskuntien suhdetta ja suhtautumista työhön. Tämä on kirjan pääteema ja liittyy tiiviisti kysymykseen työn välineellisestä luonteesta.

\section{HIGH HOPES}

Kirjan toinen osa käsittelee erilaisia työhön kohdistettuja odotuksia, jotka ovat nykyisin valtavat. Osa lähtee liikkeelle luvulla, jossa analysoidaan eurooppalaisia näkemyksiä. Euroopassa työlle on annettu jo pitkään suuri merkitys, minkä vuoksi tätä eräänlaista "Euroopan erityistietä" on tarpeen pohtia erikseen. Osio perustuu edellä mainittuihin aineistoihin, ja se paljastaa, kuinka Etelä-Euroopan maissa, mukaan lukien Ranska, työlle annetaan erittäin suuri merkitys (60-70 prosenttia tutkitusta väestöstä ilmoittaa työn erittäin tärkeäksi tekijäksi elämässään). Pohjois-Euroopan maissa työ sen sijaan ei näyttele elämässä yhtä suurta roolia. Kiinnostavaa on, että tutkimuksen mukaan Suomessa vain reilu 30 prosenttia tutkituista ilmoittaa työn kaikkein tärkeimmäksi asiaksi elämässään. Yleisesti vauraissa maissa työ ei näyttele yhtä suurta roolia kuin köyhemmissä, joskin tässä on poikkeuksia, kuten Eesti vauraiden Pohjois-Euroopan maiden joukossa ja vauras Ranska Etelä-Euroopan maiden joukossa. Myös uskonnolliset ja kulttuuriset erot vaikuttavat: protestanttisissa maissa työ ei yllättäen ole niin tärkeää kuin katolisissa maissa
- siis päinvastoin mitä Max Weber aikoinaan väitti. Luultavasti suurin syy löytyy kuitenkin työttömyydestä: maissa, joissa on korkea työttömyys, työtä arvostetaan.

Toiseksi kirjoittajat tarkastelevat työn keskeisyyden roolia erilaisten kyselytutkimusten kautta niin Ranskassa kuin vertailualueella Quebecissä. Yleisenä linjana on, että työtä tärkeämpää ihmisille vaikuttaa olevan perhe ja työn toivotaan olevan mahdollisimman hyvin sovitettavissa yhteen perhe-elämän kanssa.Perheelle haluttaisiin myös enemmän aikaa. Tutkijat kuitenkin huomauttavat viitaten Mercuren ja Vulturin Quebecissä tekemään tutkimukseen, kuinka voidaan huomata kaksi toisistaan eroavaa ryhmää: ne, joille työ näyttelee tärkeää roolia uran ja itsensä toteuttamisen muodossa, sekä ne, joille työ tulee vasta perheen, ystävien ja vapaa-ajan jälkeen, minkä vuoksi työelämältä ei välttämättä odoteta yhtä paljon kuin urasuuntautuneiden ihmisten parissa.

Kolmanneksi kysytään, "mitkä työn ulottuvuudet ovat määrääviä Euroopassa?” Tässä osassa pohdinta koskee erityisesti velvollisuusetiikan heikentymistä ja itsen toteutuksen etiikan lisääntymistä. Esimerkiksi 85 prosenttia portugalilaisista ja 75 prosenttia tanskalaisista näkee, että työ on yhteiskunnallinen velvollisuus. Sen sijaan vain 63 prosenttia ranskalaisista ja 61 prosenttia englantilaisista kokee samoin. Niissä maissa, joissa työtä ei koeta vahvasti yhteiskunnalliseksi velvollisuudeksi, ei myöskään rahan saantia ilman työtä pidetä niin ongelmallisena. On tietenkin selvää, että niissä maissa, joissa sosiaaliturva on erittäin heikko tai sitä ei ole lainkaan, rahan saaminen yhteiskunnalta ilman työtä vaikuttaa vieraalta. Toisaalta niissä maissa, joissa on hyvä sosiaaliturva, palkan suuruutta ei nähdä niin tärkeäksi asiaksi. Hyvä sosiaaliturva näyttäisi siis ihmisten mielissä johtavan maltillisempiin palkkavaatimuksiin. Tutkimuksen mukaan kaikissa muissa Pohjoismaissa paitsi Suomessa työ on siis paljon muutakin kuin keino elättää itsensä. Ranskassa työ nähdään suoraan yksilöllisen ja perheen hyvinvoinnin ja "kukoistuksen" ta- 
kaajana, kun taas Pohjoismaissa työ ei ole niin vahvasti kiinnittynyt näihin.

Neljänneksi pohditaan työhön kohdistettuja odotuksia. Taloudellisten ja välineellisten odotusten lisäksi kirjoittajat erottelevat kolme erilaista odotushorisonttia. Näistä ensimmäinen koskee yksilöä, siis sitä, kuinka ihmiset voivat toteuttaa ja mitata kykyään työelämässä, mikä liittyy suoraan kokemukseen itsensä toteuttamisesta. Toiseksi erottuvat yhteisölliset suhteet ja työilmapiiri. Työssä voidaan siis kohdata toisia ja tehdä yhteisiä asioita. Tämä on erityisen tärkeää ihmisille, joilla ei ole perhettä. Kolmanneksi työhön liittyy uraodotuksia, joissa olennaista on edistyminen ja kehittyminen uralla. Kyselytutkimuksissa ihmiset korostavat työilmapiirin tärkeyttä, sillä se on keskeinen hyvän työn osatekijä. Yhtä tärkeänä nähdään työn kiinnostavuus. Kyselyn mukaan työ on kiinnostavaa silloin, kun se ei ole monotonista tai rutiininomaista ja kun se mahdollistaa kehittymisen. Luova työ on tässä mielessä erityisen arvostettua. Ihmiset myös arvostavat yleisesti sitä, että heidän työnsä koetaan tärkeäksi. Taloudellisista odotuksista voidaan lyhyesti mainita se, että pienipalkkaiset ja / tai prekaarissa työsuhteessa työskentelevät ihmiset asettavat työstä saadun taloudellisen hyödyn kaikkein tärkeimmäksi asiaksi. Ihmiset eivät siis toisin sanoen tee prekaareja töitä "kutsumusammatteina", kuten joskus annetaan ymmärtää.

Viidenneksi tässä osiossa käsitellään työhön liittyvää "ranskalaista paradoksia", jossa törmäävät ihmisten omat unelmat hyvästä työelämästä ja toisaalta todellinen työelämä. Toisin sanoen paradoksi muodostuu siitä, että ranskalaiset näkevät työn keskeisenä elämässään, mutta samalla haluaisivat, että sen rooli pienenisi. Käytännössä ihmiset siis toivovat työajan lyhentämistä edelleen. Méda ja Vendramin löytävät tähän neljä syytä. Ensimmäinen näistä kertoo pahoinvoinnista työelämässä. Toiseksi edellistä seuraten erilaiset työn uudenlaiseen organisaation liittyvät ongelmat, stressi ja terveysongelmat johtavat siihen, että ihmiset eivät viihdy työelämässä. Kolmanneksi ihmiset eivät koe, että he voisivat toteuttaa itseään ja identiteettiään tarpeeksi työssään. Neljänneksi elämän muut osa-alueet koetaan usein liian alistetuiksi työlle, minkä vuoksi sen määrää halutaan vähentää.

\section{TYÖELÄMÄN MULLISTUKSET MUUTTAVAT MYÖS ELÄMÄÄ}

Kirjan kolmannessa osiossa siirrytään tarkastelemaan niitä työhön liitettyjä, yleensä myös hyvään elämään liittyviä odotuksia, jotka törmäävät työn suuriin muutoksiin. Tämä osio jakaantuu kolmeen, joista ensimmäinen käsittelee työn organisaation suuria muutoksia. Keskiössä ovat työn joustavuuden vaatimukset, jotka muuttavat työmarkkinat fragmentaarisiksi, hajanaisiksi ja epävarmoiksi - toisin sanoen prekaareiksi. Käytännössä suuri muutos saa alkunsa 1990-luvulla, jolloin "kolmenkymmenen kukoistuksen vuoden", siis toisen maailmansodan jälkeisen fordismin, täystyöllisyyden ja hyvinvointivaltion rakennuksen aika tulee päätökseen. Fordismin aikakauden vahvat ammattiliitot, jotka perustuivat maskuliinisiin, homogeenisiin ja tiiviisiin kollektiiveihin, murtuvat ja muuttuvat. 1990-luvulta lähtien alkaa muotoutumaan työn uudenlaisen organisaation aika, joka ei ole enää jälki-tayloristista tai uusfordistista.

Työn organisaation uudet muodot voidaan jakaa kahteen pääkategoriaan, joustavaan työhön ja epävarmaan työhön, jotka molemmat löytävät perustansa tietoteknisestä vallankumouksesta sekä yleisestä markkinatalouden logiikasta, joka huolehtii ennen kaikkea kilpailukyvystä ja voittojen maksimoinnista. Nämä asiat ovat johtaneet puolestaan erimerkiksi työn ulkoistamiseen ja sen vuokraamiseen, siis yleisesti työn ja työsuhteiden monimuotoistumiseen. Kaiken läpäisevänä ilmiönä ja vaatimuksena nousee esiin myös työn yksilöllistyminen. Kirjoittajat käsittelevät niin työn joustavuutta kuin työn epävarmuut- 
ta ansiokkaasti. Joustavuus koskettaa kaikkia työhön liittyviä asioita: työsopimusta, työpaikkaa, työaikaa, koulutusta, urakehitystä ja palkkaa. Heidän mukaansa juuri vaatimukset työn joustavoittamiseksi ovat työelämän yleisen sirpaloitumisen ja haurastumisen keskiössä.

Osa-aikaiset työsuhteet ovat olleet kasvussa koko Euroopan tasolla (vuonna 200012 prosenttia, vuonna 201114 prosenttia), ja erityisesti nuoret sukupolvet työskentelevät" "epätyypillisissä” töissä; tämä koskee jopa 40 prosenttia nuorista. Epätyypilliset työsuhteet johtavat myös kaikkein yleisimmin prekaariin asemaan niin työmarkkinoilla kuin elämässä. On myös huomattava, että työtä tehdään nykyisin 24/7, mikä tarkoittaa epätyypillisten työaikojen, kuten yötöiden, lisääntymistä. Yleisesti vanhemmat sukupolvet työskentelevät pysyvämmissä työsuhteissa ja hitaammin muuttuvissa organisaatioissa, kun taas nuoret työskentelevät useammin nopeasti kehittyvissä, muuttuvissa ja joustavissa organisaatioissa tilapäisissä työsuhteissa.

Joustavan työn lisäksi Méda ja Vendramin nostavat esiin työn epävarmuuden. Monissa maissa, mukaan lukien Suomi, kysymystä työn epävarmistumisesta ja prekarisoitumisesta ei aina oteta riittävän tosissaan. Prekarisaatio nähdään joko ohimenevänä, talouden suhdanteisiin liittyvänä vaiheena tai sitten merkityksettömänä, pääasiassa naisten työlle tyypillisenä, mutta suuressa mittakaavassa marginaalisena ilmiönä. Kirjoittajat kuitenkin osoittavat, että työn epävarmistuminen ei liity talouden suhdanteisiin vaan pikemminkin koko talousjärjestelmän ja sitä myöten työn organisaation muutokseen.

Epävarma työ on kasvussa koko Euroopassa. Vuosien 2005 ja 2010 välissä koko Euroopan keskiarvo on noussut neljästätoista kuuteentoista prosenttiin. Tässä yleisessä kehityskulussa on kuitenkin paljon Euroopan sisäistä variaatiota. Esimerkiksi Espanjassa epävarman työn määrä on kasvanut vuoden 200515 prosentista vuoden 2010 24,5 prosenttiin. Kaikkein suurinta työn epävarmuus on haalaritöis- sä uusliberaalissa Tshekissä, jossa epävarmoja työsuhteita on 52 prosenttia.

Työn epävarmistuminen on tarkoittanut myös työssäkäyvien köyhien määrän lisääntymistä. Tähän liittyy ammatillisen järjestäytymisen vähentyminen, mikä puolestaan kytkeytyy moniin erilaisiin työstä käytäviin ja työelämään kohdistettuihin poliittisiin, pääasiassa uusliberaaleihin projekteihin. Saksan malli on hyvä esimerkki siitä, kuinka talous voi kukoistaa ja työttömien määrä olla pieni, mutta tästä huolimatta prekaarin työn ja työssäkäyvien köyhien määrä on kasvussa. Vuonna 2009 koko Euroopassa 8 prosenttia työntekijöistä oli köyhiä tai eli köyhyysrajalla (tulot 60 prosenttia maan keskiansioista). Suomessa tämän tutkimuksen mukaan vain 4 prosenttia työssäkäyvistä elää köyhyysrajalla, kun taas Romaniassa luku on 18 prosenttia. Saksassa luku on 7 prosenttia. Yhtenä ratkaisuna näihin ongelmiin on pidetty niin sanottua "flexicurity"-mallia, jonka avulla pyritään yhdistämään työmarkkinoiden joustavuus ja riittävä turva työntekijöille. Kuten kirjoittajat toteavat, toistaiseksi flexicurity on kuitenkin ollut lähinnä poliittinen iskulause, joka on tuottanut joustavuutta työnantajien ehdoilla, mutta ei niinkään turvaa.

Työn joustavuuden ja epävarmistumisen tendenssien analyysin jälkeen kirjoittajat nostavat esiin palkkatyösuhteen yksilöllistymiskehityksen sekä subjektiivisuuteen liitetyt vaatimukset. 1990-luvulta lähtien työhön on alettu liittää ajatuksia yhä kasvavasta vapaudesta sekä työn rikkaudesta, autonomisuudesta, luovuudesta ja vastuullisuudesta. Itseorganisoituva työntekijä onkin tämän päivän työntekijän ihannetyyppi ja malli. Tämä liittyy myös osaltaan siihen, että nykyaikaisessa tuotannossa työaikaa ja työtehoa on yhä vaikeampaa mitata. Luc Boltanskin ja Éve Chiapellon tutkimuksia (Le Nouvel Esprit du capitalisme) mukaillen kirjoittajat esittävät, että nykytyössä työorganisaation ihannemallina on hierarkioiden vähäisyys tai niiden puuttuminen kokonaan sekä joustava, innovoiva ja erittäin kyvykäs ja osaava verkostomainen organisaa- 
tio. Tämä ei siis koske ainoastaan yrittäjiä tai yrittäjämäisiä työntekijöitä (entreployees) vaan myös aivan tavallisia palkkatyöläisiä.

Nykyisessä palkkatyössä työsuhteet siis yksilöllistyvät ja samalla yksilöiltä vaaditaan pitkälle vietyä itseohjautuvuutta. Samanaikaisesti tämän kehityksen kanssa vaaditaan kommunikaation lisäämistä työssä ja työelämässä yleisesti sekä autenttisten ihmissuhteiden, siis lähes kaverimaisen sosiaalisuuden tuomista mukaan työyhteisöihin. Ilman hyvää yhteistyötä itsenäisten toimijoiden välillä projektit eivät etene. Ei siis mikään ihme, että sosiaalisia suhteita ja verkostoja pyritään tuottamaan, työstämään ja hallitsemaan yhä tarkemmin myös tietoteknisin apuvälinein.

Työn perustavan organisatorisen mallin kehittyessä yksilölliseen suuntaan myös työntekijät alkavat nähdä työn yhä enemmän itsensä toteuttamisen alueena. Työn ajatellaan olevan osa omaa ammatillista ja jopa henkistä kehitystä. Toisaalta kirjoittajat nostavat esiin työhön liittyvän epävarmuuden ja sen, kuinka nykyaikainen työelämä tarjoaa hyvin vähän tulevaisuuden horisontteja: työtä tehdään jatkuvasti nyt-hetkessä. Eräässä mielessä tämä on myös poliittisen hallinnan malli: voimakas vaatimus keskittymisestä vain siihen mikä tapahtuu tässä ja nyt hävittää ulottuvuudet ja kysymykset koskien sitä, mitä itse asiassa tehdään, miksi ja mitä varten. Vaikka työ onkin siis itsetoteutuksen paikka, on se myös jatkuvan selviämisen, oman pätevyyden osoittamisen ja todistamisen alue. Kun tähän yhdistetään pysyvä huoli työn jatkumisesta, saatetaan työhön päätyä panostamaan liikaa. Tämä puolestaan johtaa elämän yksipuolistumiseen ja lopulta altistaa työstä johtuville fyysisille ja henkisisille sairauksille ja muille psykososiaalisille riskeille.

Kolmannen osan lopussa kirjoittajat kiinnittävät huomion pätevyysvaatimusten muutoksiin. Myös pätevyys kytkeytyy epävarmaan työhön, sillä koulutuksella ja työkyvyn ylläpidolla on suhde yksilön työllistyvyyteen. Toisin sanoen ilman koulutusta ja asianmukaisia työkykyjä on vaikea työllistyä, mutta toisaalta myöskään koulutus (jota kirjoittajat kutsuvat osuvasti "tutkintojen bulimiaksi") ei takaa mitään varmaa, kuten Suomenkin korkeat tohtoreiden työttömyysluvut kertovat. Erilaisten taitojen ja kykyjen lisäksi on tärkeää "oppia oppimaan" eli päivittämään omaa osaamista jatkuvasti. Monet työt vaativat eräänlaista moniammatillisuutta, joka edellyttää käytännössä uusien taitojen opettelua työn ohella. Tämä on yksi versio työelämän uusista joustavuusvaatimuksista.

Kirjoittajat toteavat, että työelämän laadusta on muodostunut yksi keskeisimmistä poliittisista kysymyksistä nykypäivänä. Kamppailu pääsystä hyvään työelämään - mikä usein tarkoittaa myös hyvää tai erittäin hyvää taloudellista asemaa - on kiihtynyt. Tätä kamppailua käytetään ilmiselvästi hyväksi työmarkkinoilla, sillä työntekijät ovat valmiita monenlaisiin joustoihin, itsenäiseen ja palkattomaan opiskeluun, terveydestä huolehtimiseen ja niin edelleen turvatakseen työkykynsä ja työllistettävyytensä. Työelämä näyttäytyy itsensä toteuttamisen alueena, mutta se on yhtä lailla myös lisääntyvän kontrollin ja työmarkkinoiden sanelemien ehtojen tuottaman sisäistetyn itsekontrollin alue.

\section{UUDENLAISET TYÖNTEKIJÄTYYPIT}

Kirjan neljäs osio laajentaa tarkasteluperspektiiviä sukupolvien välisiin vertailuihin pohtimalla työn merkitystä ja siihen liitettyjä arvoja. Se keskittyy siis tarkastelemaan yhtäältä nuorten ja toisaalta vanhempien sukupolvien suhdetta työhön. Kirjoittajat kuitenkin huomauttavat, että sukupolven käsitteelle ei ole yhtä selvää määritelmää, eikä näin tule ollakaan. Sen sijaan he erottavat poliittisten, kulttuuristen ja taloudellisten sukupolvien käsitteet, mikä tuo lisää analyysimahdollisuuksia. Yhtenä mahdollisena analyyttisenä erotteluna kirjoittajat tarjoavat myös toisen maailmansodan jälkeistä "babyboomers"-sukupolvea erotettuna 1990-luvun jälkeisten "baby-losers"-sukupolvesta. Näistä 
jälkimmäinen on prekaari sukupolvi, joka on huonommin järjestäytynyt poliittisesti sekä huonommin suojeltu. Yleisesti tästä sukupolvesta käytetään nimitystä Y-sukupolvi.

Kirjoittajat lähtevät liikkeelle hahmottelemalla erilaisten työhön liittyvien orientaatioiden typologiaa. Tätä typologiaa rakenteistaa kaksi asiaa: yhtäältä kahtiajako suhtautumisessa työhön joko välineellisenä tai itsen ilmaisun välineenä ja toisaalta elämänkulun kysymykset. Kirjoittajat hahmottelevat myös J. Cultiauxin ja P. Vendraminin ehdotuksen pohjalta eräänlaisen työhön suhtautumisen nelikentän. Heidän mukaansa työhön suhtautumista määrittää ensiksikin se, suhtaudutaanko siihen työnä (travail) vai ansiotyönä (emploi). Nelikenttää jäsentää yhtäältä se, sitoudutaanko työhön käytännöllisesti vai itsen ilmaisun välineenä. Toisaalta sitä jäsentää kysymys elämänkulun luonteesta: onko se tavanomaista tai vaihtoehtoisesti yksilöllistä.

Näin saadaan muotoiltua neljä työhön suhtautumisen tyyppiä. Ensimmäisessä työ näyttäytyy eräänlaisena välttämättömyytenä mitä tulee materiaalisten tarpeiden tyydytykseen, mutta se ei varsinaisesti ole elämän sisältö eikä päämäärä itsessään. Toisen, erityisesti yksilöllisen elämänkulun vaikutuksesta muovautuvan suhtautumisen tyypin mukaan työ näyttäytyy vain ja ainoastaan keinona hankkia rahaa. Jos ensimmäiselle tyypille työ on osa, joskin pakollinen sellainen, yhteisöllistä ja yhteiskunnallista elämää, toiselle tyypille työ on vain täysin välineellinen hyödyke. Tällaisen suhtautumistavan omaava työntekijä ei siis juurikaan piittaa muista, vaan on hankkimassa rahaa esimerkiksi ulkomaan matkaan. Kolmannen suhtautumistavan omaava työntekijä puolestaan näkee työn tukevan henkilökohtaista kehitystä. Tällaiset työntekijät eivät varsinaisesti erottele työtä ja muuta elämää toisistaan. He ovat myös orientoituneita löytämään "unelma-ammatin". Heille työ on yhtä tärkeä tai jopa tärkeämpi kuin perhe. Tällaiset ihmiset arvostavat joustavuutta ja itsenäisyyttä, mutta he tietävät myös, että heidän tulee olla tarpeellisia muille säilyttääk- seen asemansa. Kolmannen suhtautumistyypin omaavat työntekijät ovat siis erittäin professionaaleja, ja työllä on jopa eräänlainen esteettinen merkitys heidän elämässään. Neljännelle suhtautumistyypille on ominaista pitää työtä puolestaan keskeisenä identiteetin rakennuskivenä. Sen omaavilla ihmisillä voi olla hyvin hankalia perhetaustoja, maahanmuuttajatausta tai muita suuria elämänkulkuun liittyviä haasteita. Tämän seurauksena he ovat "oman onnensa seppiä" ja he sitoutuvat työhönsä vahvasti, sillä eräässä mielessä työ on heille kaikki kaikessa. He ovat erittäin joustavia ja valmiita sovittelemaan työn ja perheen yhteen hinnalla millä hyvänsä. Eräässä mielessä he ovat siis kaikkein joustavimpia työntekijöitä.

Osion lopuksi kirjoittajat kysyvät, määrittyvätkö erilaiset työhön liittyvät suhtautumisen tavat iän, sukupuolen tai koulutustason mukaan. Sukupuolella näyttää olevan vaikutusta suhtautumiseen: miehille on tärkeämpää nouseva palkka ja eteneminen uralla, kun taas naisille on tärkeää työn itsenäisyys sekä mahdollisuus auttaa toisia ihmisiä. Maissa, joissa naiset ovat edelleen paljon kotona tai osa-aikatöissä (esim. Saksa, Ranska ja Italia), sukupuolella on suuri merkitys suhtautumisessa työhön. Nykytyön vaatimuksissa ura ja työ menevätkin usein perheen edelle, eivätkä uraohjautuneet naiset aina perusta lainkaan perhettä.

Myös iällä ja sukupolvella on vaikutusta työhön suhtautumiseen. Yhden konfliktiriskin työpaikoilla voi aiheuttaa nuorten ja vanhojen työntekijöiden erilaisten käsitysten ja toimintatapojen törmäys. Nuoret ovat usein koulutetumpia, mutta mahdollisesti heidän solidaarisuutensa muita työntekijöitä ja yhteiskuntaa kohtaan yleisesti voi olla pienempää. Yhden ongelman muodostaa työmarkkinoiden epävarmuuden aikaansaama pelko, joka vaikuttaa erityisesti nuoriin ikäpolviin. Nuoret eivät luota työnantajiin, vaan ovat tottuneet pätkätöihin ja voivat toisaalta odottaa "sitä oikeaa" työtä, mikä johtaa vähäisempään sitoutumiseen kuin vanhemmilla ikäpolvilla. On tunnettua, että nuoret eivät välttämättä panosta työhönsä kovinkaan 
paljon. Olisikin kysyttävä, miksi näin on. Työmarkkinoiden epävarmuus on vahva kandidaatti tähän heikkoon motivaatioon ja sitoutumiseen.

Kirjoittajat toteavatkin, että todennäköisesti juuri nuorten sukupolvien ja naisten kohtaamat kokemukset työelämässä määrittelevät koko työelämän tulevaisuuden suuntaa. Työelämä ja elämä kokonaisuudessaan ovat muuttumassa monikeskeisiksi ja toisaalta epävarmoiksi. Työ on menettämässä asemaansa yksilön ja yhteiskunnan keskeisimpänä asiana, vaikka samalla siitä on tulossa yhä tärkeämpi asia ihmisten taloudellisessa selviytymisessä, sillä sen puuttuminen on entistä suurempi syrjäytymisriski.

\section{SUKUPOLVET TYÖSSÄ JA YHTEISKUNNASSA}

Kirjan viides ja viimeinen osio pohtii sitä, kuinka eri sukupolvet voivat osallistua samaan työelämään yhdessä. Sen neljästä luvusta ensimmäinen pohtii iän vaikutusta ihmisten välisiin suhteisiin, eri ikäisten ihmisten suhtautumista toisiinsa ja käyttäytymistä toisiaan kohtaan. Haastatteluaineistoihin perustuen tutkijat esittävät, että usein vanhemmat työntekijät näkevät nuoret huonosti motivoituneina, eikä nuorilla nähdä olevan riittävää kiinnostusta työhön. Vanhemmat myös kokevat, että nuoret tyytyvät liian helposti elämään epävarmuudessa ja lyhytaikaisissa työsuhteissa. Jopa työttömyys nähdään usein nuoren heikosta motivaatiosta riippuvaksi. Jää usein huomaamatta, kuten kirjoittajat korostavat, että monet nuoret työntekijät saa alistuviksi ja hiljaisiksi pääasiassa työttömyyden ja prekaarisuuden pelko.

Toisaalta myös vanhempiin työntekijöihin liitetään monia asiattomia stereotypioita. Heidät nähdään vähän koulutetuiksi, pysähtyneiksi ja kyvyttömiksi muutoksiin. Nuoret myös kokevat helposti, että vanhemmat eivät halua kehittää itseään tai työtään, vaan haluavat "tehdä kaiken aina samalla tavalla". Nuoriin liitetään myös mielikuvia yltiöyksilöllisyy- destä, kun taas vanhoihin mielikuva vahvasta solidaarisuudesta. Ongelmallista on, jos näistä asioista ja usein vääristä mielikuvista ei puhuta avoimesti, sillä mahdollisten konfliktien syntyessä nämä ennakkoluulot toimivat eräänlaisena jännitteitä ruokkivana resurssina, joka puolestaan johtaa työntekijöiden keskinäisiä suhteita ja solidaarisuutta väärään suuntaan.

Toiseksi osassa tarkastellaan sitä, kuinka työkokemus muodostuu ja vaikuttaa ja minkälaisia yksilöllisiä reittejä prosesseihin liittyy. Kirjoittajat korostavat erityisesti nuorempiin ikäpolviin kohdistuvaa työn prekaarisuuden vaikutusta. Vanhat työntekijät näkevät nuorten tilanteen hankalaksi ja pitävät juuri nuoria prekaarina sukupolvena. Vanhat näkevät myös, kuinka nuoria muutoinkin kohdellaan huomattavasti tiukemmin kuin muita: heihin suhtaudutaan kylmästi, kyynisesti, heitä testataan, heidät laitetaan koeajoille, heitä motivoidaan ja aktivoidaan. Olisi kuitenkin huomattava, että nykyisin nämä käytännöt koskevat kaikkia työntekijöitä ja myös iäkkäämpien työntekijöiden on huomattavan vaikea löytää töitä erilaisten pätkien välissä.

Kolmanneksi kirjoittajat nostavat esiin ne jännitteet, joita liittyy kokemukseen, muodolliseen tietoon ja innovaatioihin. Tässä luvussa huomio on erityisesti "diginatiivien" sukupolven ja vanhempien sukupolvien suhteissa. Tietotekniset taidot ja muut työhön liittyvät taidot eivät välttämättä löydy samoista henkilöistä - minkä takia saattaa syntyä törmäyksiä. Kirjoittajat nostavat esiin myös sen, kuinka kyky innovaatioihin asettuu joskus vastakkain työkokemuksen kanssa. Vanhoja työntekijöitä pidetään loogisempina, heidän työnsä arvioidaan paremmin jäsentyneeksi eikä heidän nähdä käyttäytyvän yhtä eksessiivisesti kuin nuorten. Toisaalta nuoret pitävät itseään nopeina oppimaan uusia asioita ja soveltamaan asioita"lennosta". Erityisesti jälkimmäinen vaikuttaa olevan vanhemmille ikäpolville vaikeaa. Nuorille työ on siis joustavampaa kokonaisuudessaan, myös työn sisältöjen ja työsuoritusten tasolla. Tämä voi toisaalta johtaa siihen, että asioita tehdään jat- 
kuvasti kuin ne olisivat uusia. Nuoret ovat myös innovatiivisempia kuin vanhemmat.

Viimeisten vuosikymmenten muutokset työelämässä ovat selvästi edistäneet nuoremman sukupolven astumista työelämään, eivätkä vanhemmat näytä aina pysyvän muutoksessa mukana. Jos työelämä muuttuu siis vaikeammaksi ja tiukemmaksi nuorten ikäpolvelle, voivat nämä vaatimukset olla liiallisia ja tuhoisia myös niille vanhemmille työntekijöille, jotka joutuvat kilpailemaan työpaikastaan nuorten kanssa. Olennaista hyvän työelämän rakentamisessa olisi rakentaa työilmapiiriä, jossa sukupolvien erot tunnistetaan, mutta niitä ei käytetä vihamielisen ilmapiirin luomiseen.

Osion yhteenvetona kirjoittajat miettivät, millaista on eri sukupolvien läheisyys ja etäisyys työelämässä. On selvää, että nuoret kokevat yhteiskunnan pettäneen heille annetut lupaukset koulutuksen ja työn hyödyllisyydestä. Jos eurooppalaiset yhteiskunnat eivät kykene luomaan uudenlaista tulevaisuuden ja toivon horisonttia nuorille, on todennäköistä, että sitoutuminen ja motivaatio työhön heikkenee edelleen.

\section{LOPUKSI}

Kirjan lopussa Dominique Méda ja Patricia Vendramin palaavat kaikkein suurimman kysymyksen äärelle: onko työtä mahdollista ajatella ja tehdä yhteiskunnassa uudella tavalla. Heidän mukaansa työstä on tullut viimeisten vuosikymmenten aikana tärkein "utopististen energioiden investoimiskohde". Toisin sanottuna työhön kohdistetaan ja siltä odotetaan huomattavan suuria asioita niin yksilöiden kuin yhteiskuntien elämässä. Ranskan sana le travail juontuu keskiajalta, jolloin sen merkitys viittasi kärsimykseen. Nykyisin työ on sen sijaan ensisijaisesti keino muiden päämäärien toteuttamiseen, siis ennen kaikkea rikkauden luomiseen ja palkan ansaitsemiseen. Nämä molemmat liittyvät valtaan, hallintaan sekä kulutuksen lupaamiin rajattomiin mahdollisuuksiin. Nykyisin työ tarkoittaa myös vapautumista ja itsenäisyyttä. Sitä on pidetty keinona muuttaa maailmaa ja tehdä siitä ihmisten oma kuva. Työ on nähty myös yhteiskuntien keskeisimpänä integraation välineenä.

Työ näyttää yhtäältä toteuttaneen näitä utopioita, mutta toisaalta työ on menettänyt roolinsa yhteiskunnallisen integraation tuottajana. Työelämästä on tullut yksilöllisempää, mihin liittyy monia opportunistisia, individualistisia, agonistisia ja jopa kyynisiä arvoja. Etenkin osa nuorista koulutetuista ikäpolvista on valmiita omistamaan elämänsä työlle, josta he saavat niin taloudellisen turvan kuin yksilöllisen tyydytyksen. Työn yhteiskunnalliset ulottuvuudet ovat sen sijaan jäämässä takaalalle, eikä niitä juurikaan arvosteta.

Työvoiman polarisaatio hyvin menestyviin tietotyöläisiin ja luovan alan työläisiin sekä toisaalta matalapalkkaisiin prekaareihin töihin kiihdyttää tätä tendenssiä. Työn uuteen fragmentaariseen ja prekaariin organisaatioon liittyvät muutokset siis kiihdyttävät myös koko yhteiskunnan ja väestön polarisaatiota. Työn muuttuminen yksilökeskeiseksi ja itsekkääksi toiminnaksi uhkaa viedä huomion pois aikakautemme keskeisestä yhteiskunnallisesta kysymyksestä, nimittäin ekologisesta kriisistä ja sen ratkaisemisesta. Siksi työn merkitys ja mieli, syy tehdä töitä ja tuottaa hyödykkeitä, pitäisi miettiä kokonaan uudestaan. Rikkauden kasaamisen tahti on yksinkertaisesti liian kiivas, ja se uhkaa tuhota niin ympäristön kuin yhteiskunnan. Siksi kirjoittajat esittävät, että työ tulisi keksiä uudelleen "sivistyneenä työnä", joka toimii yhteiskunnan ja ympäristön asettamien reunaehtojen puitteissa, mahdollistaen samalla ihmisten hyvän elämän kansalaisina, vanhempina ja ystävinä - ei pelkkinä rikkauskoneen äärimmilleen hyväksikäytettyinä, mutta kertakäyttöisinä osina. 